\title{
Buerger's disease
}

Matthew Megson, ${ }^{1}$ Michael Collins, ${ }^{2}$ Simon Hobbs $^{1}$

${ }^{1}$ Department of Vascular Surgery, New Cross Hospital, Wolverhampton, UK ${ }^{2}$ Department of Radiology, New Cross Hospital, Wolverhampton, UK

\section{Correspondence to}

Dr Matthew Megson, matthew.megson@nhs.net

Accepted 15 October 2015

\section{DESCRIPTION}

The angiogram and the photograph are from a 27-year-old man, a heavy smoker, who was admitted with ulcerated and necrotic lesions on the toes of both his feet, as shown in figure 1. In figure 2, the arteries are normal to the level of the mid-calf, where they abruptly occlude and are replaced by corkscrew collateral vessels, classical of thromboangiitis obliterans (Buerger's disease). This is an inflammatory disease of small-sized and mediumsized arteries and occurs almost exclusively in male heavy smokers aged 20-40 years. Treatment requires complete and immediate smoking cessation. Intravenous prostacyclin (eg, iloprost) may help with symptom control. Major amputation is common in those who continue to smoke.

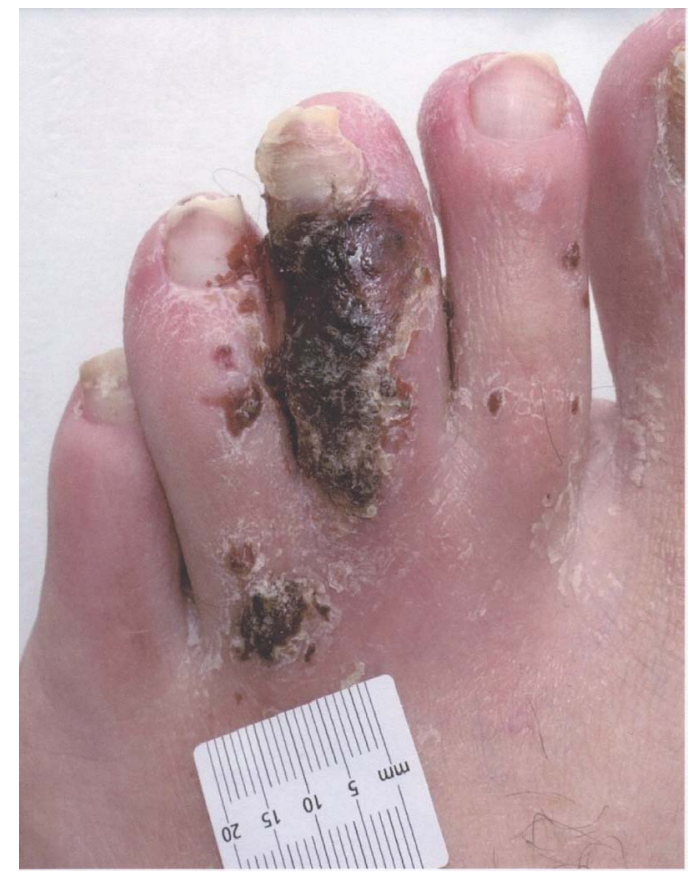

Figure 1 The ulcerated and necrotic lesions on the toes of the feet.

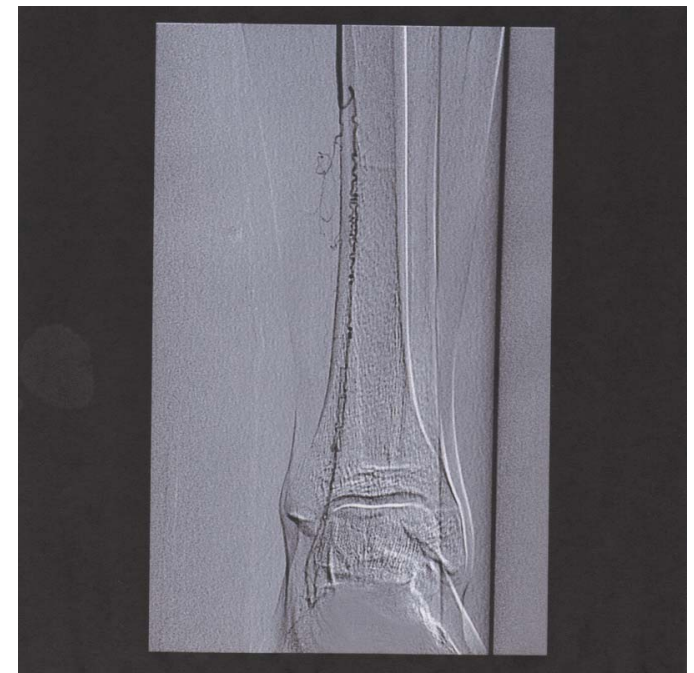

Figure 2 Corkscrew collateral vessels, classical of thromboangiitis obliterans (Buerger's disease).

\section{Learning points}

- These patients require smoking cessation assistance.

- If these patients do continue to smoke, they often require amputation, therefore early counselling with an amputation service/ physiotherapists is useful.

Contributors MM and SH wrote the case report and obtained consent. MC performed the angiogram. SH reviewed the work.

Competing interests None declared.

Patient consent Obtained.

Provenance and peer review Not commissioned; externally peer reviewed.

Copyright 2015 BMJ Publishing Group. All rights reserved. For permission to reuse any of this content visit http://group.bmj.com/group/rights-licensing/permissions.

BMJ Case Report Fellows may re-use this article for personal use and teaching without any further permission.

Become a Fellow of BMJ Case Reports today and you can:

- Submit as many cases as you like

- Enjoy fast sympathetic peer review and rapid publication of accepted articles

- Access all the published articles

- Re-use any of the published material for personal use and teaching without further permission

For information on Institutional Fellowships contact consortiasales@bmjgroup.com

Visit casereports.bmj.com for more articles like this and to become a Fellow 